Jolanta J. Adamczyk

\title{
Applications of self-organizing map for patterning macrofungal diversity of xerothermic swards
}

Received: 6 August 2010/ Accepted: 20 January 2011/Published online: 1 March 2011

(C) The Author(s) 2011. This article is published with open access at Springerlink.com

\begin{abstract}
Macrofungal communities were investigated in four associations of xerothermic swards: Festucetum pallentis, Origano-Brachypodietum, Adonido-Brachypodietum pinnati and Diantho-Armerietum elongatae in a Jurassic area of the Czestochowa Upland (southern Poland). A total of 47 species were recorded. The selforganising map (SOM) - an unsupervised algorithm for artificial neural networks - was used to recognise patterns in the macrofungal communities of diverse xerothermic swards. Only two associations were mycologically similar: Origano-Brachypodietum and Adonido-Brachypodietum pinnati. Species with high and significant IndVal (the species indicator value) for each investigated phytocoenoses are presented. The presence of macrofungal species and the participation of indicator species were connected with habitat factors of plant associations, as documented by the IndVal application. In the least fertile phytocoenoses, macrofungal communities were poor with few indicator species. The more fertile phytocoenoses had richer and more varied communities of macrofungi with higher numbers of indicator species. The ordering methods applied in this study were very effective for analyzing the macrofungal communities existing in plant associations.
\end{abstract}

Keywords Fungi Xerothermic vegetation · Habitat factor $\cdot$ Self-organizing map $\cdot$ IndVal

\section{Introduction}

Macrofungal communities inhabiting plant associations have been the subject of much research but xerothermic swards have been examined in three localities only (Wojewoda 1974, 1975, 1977; Stasińska 2005; Adamczyk

\section{J. J. Adamczyk (ه)}

Department of Nature Protection,

Faculty of Biology and Environmental Protection, University of Łódź, 1/3 Banacha Str, 90-237 Lodz, Poland

E-mail: adamta@biol.uni.lodz.pl
2009). However, gaining knowledge on these associations is indispensable because they are seriously threatened in Poland and other European countries (Olaczek 1998). The list of macromycete species found in the swards of the Festuco-Brometea class, compiled from literature from the latest 50 years, includes only about 40 taxa (Stasińska 2008). Xerothermic swards are mentioned among habitats of especial importance in the Habitats Directive (Council Directive 92/43/EEC of 21 May 1992 on the conservation of natural habitats and wild fauna and flora). It is a well known fact that xerothermic swards are seminatural and, just for that reason, do not form stable communities. They require the constant human activity afforded by grazing by cattle and mowing (Olaczek 1998). Any attempt to widen our knowledge of xerothermic swards could be useful for their protection. Distinguishing indicator species of macromycetes for different xerothermic swards could help us to estimate changes in these plant communities, because fungi react to habitat changes more quickly than plants (Arnolds 1981).

Macromycete research on plant communities of Europe relies mainly on the phytosociological BraunBlanquet method (e.g., Ławrynowicz 1973; Wojewoda 1975; Arnolds 1994). Suitable statistical methods, such as DCA, TWINSPAN, and ACC have been applied in only a few studies (e.g., Adamczyk et al. 2004; Fraiture 2004). The Braun-Blanquet method proposed for plants permits the abundance and constancy of species at a designated site to be estimated. The method is understood rather as a plant abundance measure, as fungus fruiting body numbers do not give an indication of fungus mycelia volume (Fraiture 2008). Beside, the carpophores of one species noted on a permanent plot could be produced by different mycelia. Therefore, the frequency of macrofungal species is more significant than the number of specimens, because it indicates the occurrence of species in that community. Hence, my search for a method that will allow an objective analysis of relationships between macrofungi and plant communities of separating species, which is particularly significant for different phytocoenoses. 
The self-organizing map (SOM) algorithm and the IndVal index have not yet been applied to macromycetes communities. In this study, the SOM was used for the following reasons: (1) macromycetes community studies already published in Poland did not reveal any association between such communities and xerothermic swards; (2) the availability of very rich data means that symbols and their codes are usually illegible because they overlap (Kruk et al. 2007); and (3) we also cannot determine from gradient analysis where the border between clusters of samples or species is located in multivariate space (Cho 1997).

Xerothermic swards are found in Southern and Southeastern Europe in areas with a warm, dry climate, and they also occur extrazonally in places with a particular combination of orographic, soil and local climatic factors (Matuszkiewicz 2001). Xerothermic plant species most likely entered Poland during the Elsterian glaciation from three directions: from the Hungarian lowland through the Moravian Gate; from the southwest through Podolye; and from the southeast, i.e., from Turingia (Krzakowa and Michalak 2007). In Poland, these rare phytocoenoses are currently situated in southern and north-western parts of the country. They develop in locations characterized by high temperatures and high calcium carbonate content in the soil. Plant communities developing in such specific biotopic conditions are distinguished by characteristic species compositions with many rare taxa (Szafer 1977; Matuszkiewicz 2001).

The principal aims of this study were (1) to examine the mycological similarity of diverse xerothermic swards, and (2) to determine the indicator species (IndVal) of macrofungi for each xerothermic sward.

\section{Materials and methods}

\section{Study site}

This study was conducted from 1997 to 2000 and from 2002 to 2003 in a region of the Częstochowa Upland. The Częstochowa Upland is located in southern Poland and occupies an area of 1,299 $\mathrm{km}^{2}$ (Kondracki 1998; Dylikowa 1973). The landscape is characterized by limestone rocky crags that often have castle ruins positioned on top of them, as well as numerous caves and erosion valleys. The Mesozoic base of the Czestochowa Upland consists of Upper Jurassic limestone covered by Pleistocene deposits (Dylikowa 1973). This area has an extraordinarily rich and varied flora, including mountain and thermophilic plants, relicts and even endemics; e.g., Galium cracoviense, Saxifraga aizoon, Botrychium lunaria and Anemone sylvestris are found here (Hereźniak 2002, 2004).

The investigated xerothermic swards are situated in the northern part of the Częstochowa Upland on six calcareous hills $\left(50^{\circ} 45^{\prime} 07^{\prime \prime} \mathrm{N} 19^{\circ} 16^{\prime} 04^{\prime \prime} \mathrm{E}\right)$. Four different associations of semi-natural dry grasslands were examined: Festucetum pallentis (FP), Origano-Brachypodietum ( $\mathrm{OBr})$, Adonido-Brachypodietum pinnati (AB), and Diantho-Armeriatum elongatae (DA).

The FP association develops on steep, calcareous rocks, where soil occurs only in the interstices between rocks. The soil is rather poor in humus but rich in calcium carbonate (about 7\%). The species Festuca pallens, Thymus pulegioides, Sedum acre, Galium cracoviense and Tortula ruralis dominate the floristic composition. The coverage of the plant layer is low (about 30\%).

The $\mathrm{OBr}$ and $\mathrm{AB}$ associations develop in soil with a well developed humus horizon and calcium carbonate content equal to approximately $8 \%$. The vegetation coverage of this plant association is up to $100 \%$, and it forms high, colourful swards of several layers. Different species of grasses and sedges grow here, e.g., Brachypodium pinnatum, Festuca ovina, Agrostis canina and Carex caryophyllea. These phytocoenoses have a distinctive composition of shrubs and trees, e.g., Juniperus communis, Rhamnus cathartica, Corylus avellana and Sorbus aucuparia.

The DA association occurs on sandy soils that are poor in calcium carbonate. The vegetation coverage of this community is high $(70-100 \%)$. The floristic composition is dominated by Cerastium arvense, Armeria elongata, Dianthus deltoides, Corynephorus canescens, Scleranthus perennis, Festuca rubra and Anthoxanthum odoratum (Babczyńska 1978).

\section{Collection of samples}

In four associations of xerothermic swards, ascomycete and basidiomycete macrofungi were observed in a total of 30 permanent plots (the area of each plot was 4-50 $\mathrm{m}^{2}$ ). The size of plots and their locations were taken from the phytosociological classification by Babczyńska (1978) and Babczyńska-Sendek (1984). The presence of fungus in each site was examined every 3 weeks on 28 occasions from April to November 1997-2000 and 2002-2003. Herbarium specimens were deposited with the University Herbarium of Łódź. The species nomenclature of Ascomycota followed Dennis (1978) and Chmiel (2006), and the species nomenclature of Basidiomycota was taken from Wojewoda (2003).

\section{Statistical data analysis}

An unsupervised algorithm of an artificial neural network, i.e., a SOM, was used to recognize patterns in the macrofungi in the study area (Kohonen 1982). The advantage of this method is that it can be used to effectively analyze complex data sets despite non-linear relationships and non-normal distributions, and it results in a two-dimensional map that is easy to interpret (Kohonen 1982). The SOM has proved to be an effective and powerful tool for exploring patterns in species distributions, and the structure of communities (Chon et al. 
1996; Giraudel and Lek 2001; Penczak et al. 2005, 2009; Kruk 2006; Lasne et al. 2007; Kalteh et al. 2008; Bedoya et al. 2009). The SOM was simulated and cluster analysis was performed in Matlab (ver. 6.1.0.450). A Kohonen neural network was built of two layers of neurons (processing units): an input layer and an output layer. The number of input neurons was equal to the number of variables in the data set, i.e., the number of fungal species (47). Each input neuron was connected to all of the output neurons. During the training process, input neurons transmit signals to the output layer of neurons. The data (47 taxa $\times 30$ sites) were displayed on the input layer of neurons (i.e., processing units) 180 times in the rough training phase, and 660 times in the finetuning phase. Output layers of different sizes were examined step by step from $4 \times 4$ (16 neurons) to $8 \times 8$ (64 neurons), and an output layer of $4 \times 4$ neurons was ultimately chosen. To finally select a map size, I use the heuristic rule of Versanto et al. (2000): the map unit is $5 \sqrt{ } n$, where $n$ is the number of training samples. The actual number of neurons should be close to the number determined by Versanto's rule, but I have accepted a slightly smaller map because a $5 \times 5$ map had many empty units, which is not helpful (Céréghino and Park 2009).

Log transformed and normalized (0-1) numbers of individuals were presented to the neurons in the input layer. A batch training algorithm was used, which is significantly faster and does not require specification of any learning rate factor, and the results of the batch algorithm are not dependent on the learning order of inputs (Park et al. 2006). Generally, the SOM is a robust and useful method for ecological studies (Kalteh et al. 2008), and different training functions do not have any noticeable effect on its operation (Noori et al. 2010).

The map obtained after the training process of the SOM contained all the macrofungi sites assigned to neurons so that similar sites were located in one neuron or in adjoining neurons, and significantly dissimilar sites were in distant neurons (Chon et al. 1996; Park et al. 2003; Bedoya et al. 2009). To subdivide the output neurons into different clusters (groups) according to their similarity (Bedoya et al. 2009), I used a hierarchical cluster analysis with the Ward linkage method and Euclidean distance measurements.

To show which cluster of neurons (and their environmental conditions) was most preferred by each species, the indicator value (IndVal) defined by Dufrene and Legendre (1997) was used. This value was obtained for each species from the original untransformed data matrix (number of individuals) and was attributed to the clusters distinguished by SOM. The species that presented significant values of IndVal in any cluster were then selected using Monte Carlo statistics. The above calculations were made using PC-ORD statistical software (MacCune and Mefford 1992). To avoid drawing invalid conclusions, only species having IndVal $>25$ were taken into consideration. IndVals complement the information presented on graphs of species importance (component planes) produced by the SOM (Lasne et al. 2007; Penczak et al. 2009).

\section{Results}

A total of 47 species of macrofungi were found in the investigated xerothermic swards. The sites richest in macrofungi were located in the Origano-Brachypodietum (39 species) and Adonido-Brachypodietum pinnati associations (37 species). The poorest sites were situated in the Festuco pallentis association (13 species) (Table 1).

The trained SOM indicated three main clusters of sites assigned to the output neurons: (X) A1, A2, A3, $\mathrm{A} 4, \mathrm{~B} 2, \mathrm{~B} 3$ and $\mathrm{B} 4$; (Y1) B1, C1, C2, D1; and (Y2) C2, $\mathrm{C} 3, \mathrm{C} 4, \mathrm{D} 2, \mathrm{D} 3$ and D4 (Fig. 1). The clusters $\mathrm{X}$ and $\mathrm{Y} 1$ were homogeneous within themselves but differed from each other, essentially in the character of sites assigned to them. Cluster $\mathrm{X}$ contains all 15 sites from the FP association (neurons A2, A3, A4); cluster Y1 contains all 5 sites located in DA. These sites are situated in only one neuron $(\mathrm{C} 1)$ and separated by neighboring, wide hexagons $\mathrm{B} 1$ and $\mathrm{C} 2$ from cluster $\mathrm{X}$ and $\mathrm{C} 2$ and $\mathrm{D} 1$ from cluster Y1. Cluster Y2 is less homogeneous because it contains ten sites of two diverse xerothermic swards: $\mathrm{OBr}$ and $\mathrm{AB}$, located in three neurons: D2, D3 and D4. The sites of these two associations are mixed in two neurons, D3 and D4. Only one site, AB81, is situated in neuron D2. The wide neurons separate these sites from cluster X (C3, C4).

The IndVal showed the importance of all species of macrofungi on the SOM (Fig. 2; Table 2). Species with a high and significant IndVal for cluster $\mathrm{X}$ included Arrhenia spathulata, Hemimycea mairei $(P<0.001)$ and Geastrum minimum $(P<0.01)$. The indicator species for cluster Y1 included the following: Aleuria aurantia, Coprinus atramentarius, C. comatus, Scleroderma bovista, S. verrucosum and Vascellum pratense $(P<0.001)$; Bovista nigrescens and Melanoleuca brevipes $(P<0.01)$; and Bovista graveolens, Lycoperdon molle and Marasmius oreades $(P<0.05)$.

Cluster Y2 was the richest in species with significant IndVal values and included the following: Agrocybe pediades, A. praecox, Calocybe gambosa, Calvatia utriformis, Camarophyllus pratensis, C. virgineus, Hygrocybe persistans, Lycoperdon ericaeum and Tubaria furfuracea $(P<0.001)$; Crinipellis scabella, Lycoperdon decipiens, Marasmius scorodonius and Rickenella fibula $(P<0.01)$; and Calvatia excipuliformis, Hygrocybe psittacina, Panaeolus fimicola, P. sphinctrinus, Rickenella setipes, Telephora caryophyllea, Volvariella bombycina and $V$. pusilla $(P<0.05)$.

\section{Discussion}

Macrofungal communities had different species structures in diverse xerothermic swards. The macrofungal communities of FP and DA associations were the most 


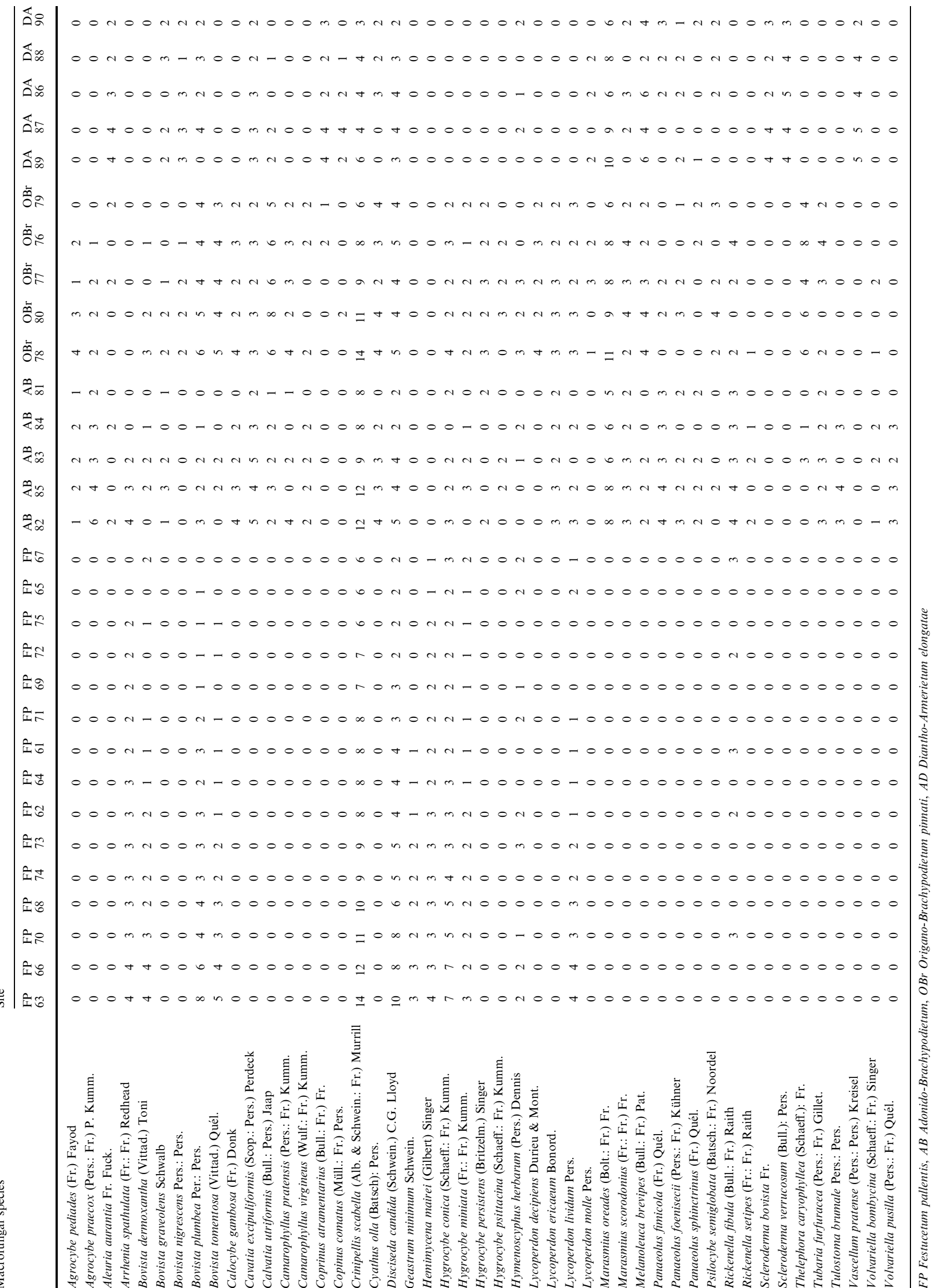




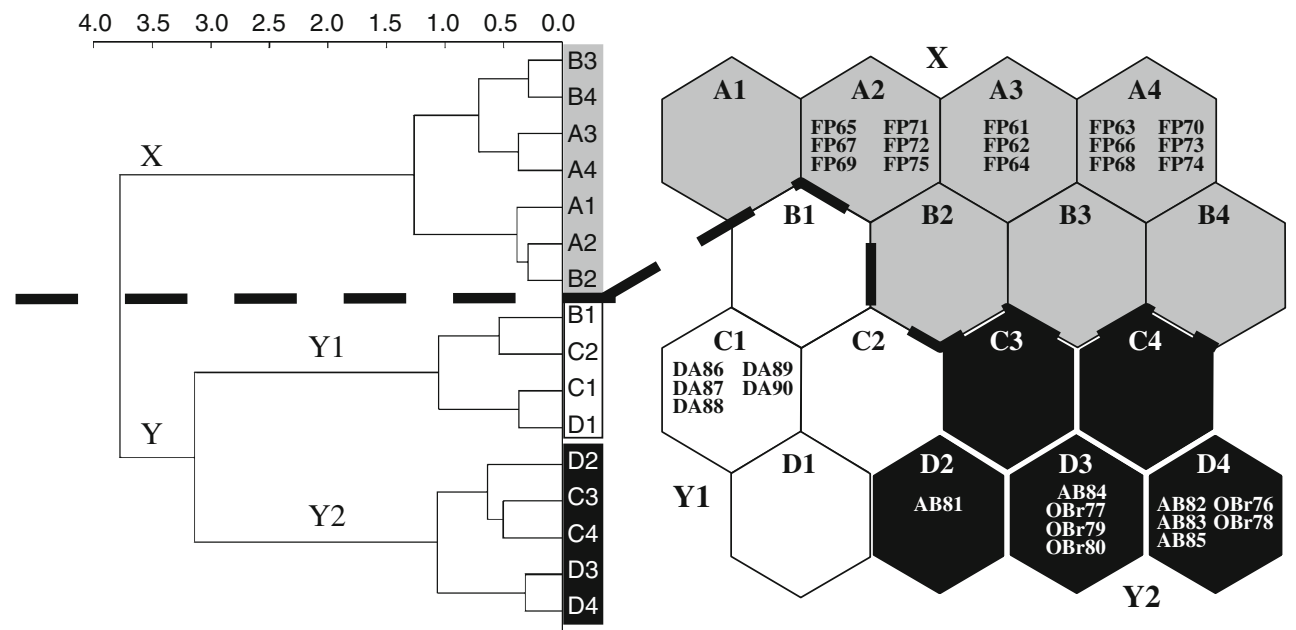

Fig. 1 The 30 sites from xerothermic swards assigned to self-organizing map (SOM) neurons. Sites are marked with codes, as explained in Table 1. Distance for clusters on the Ward diagram are marked on the $y$-axis
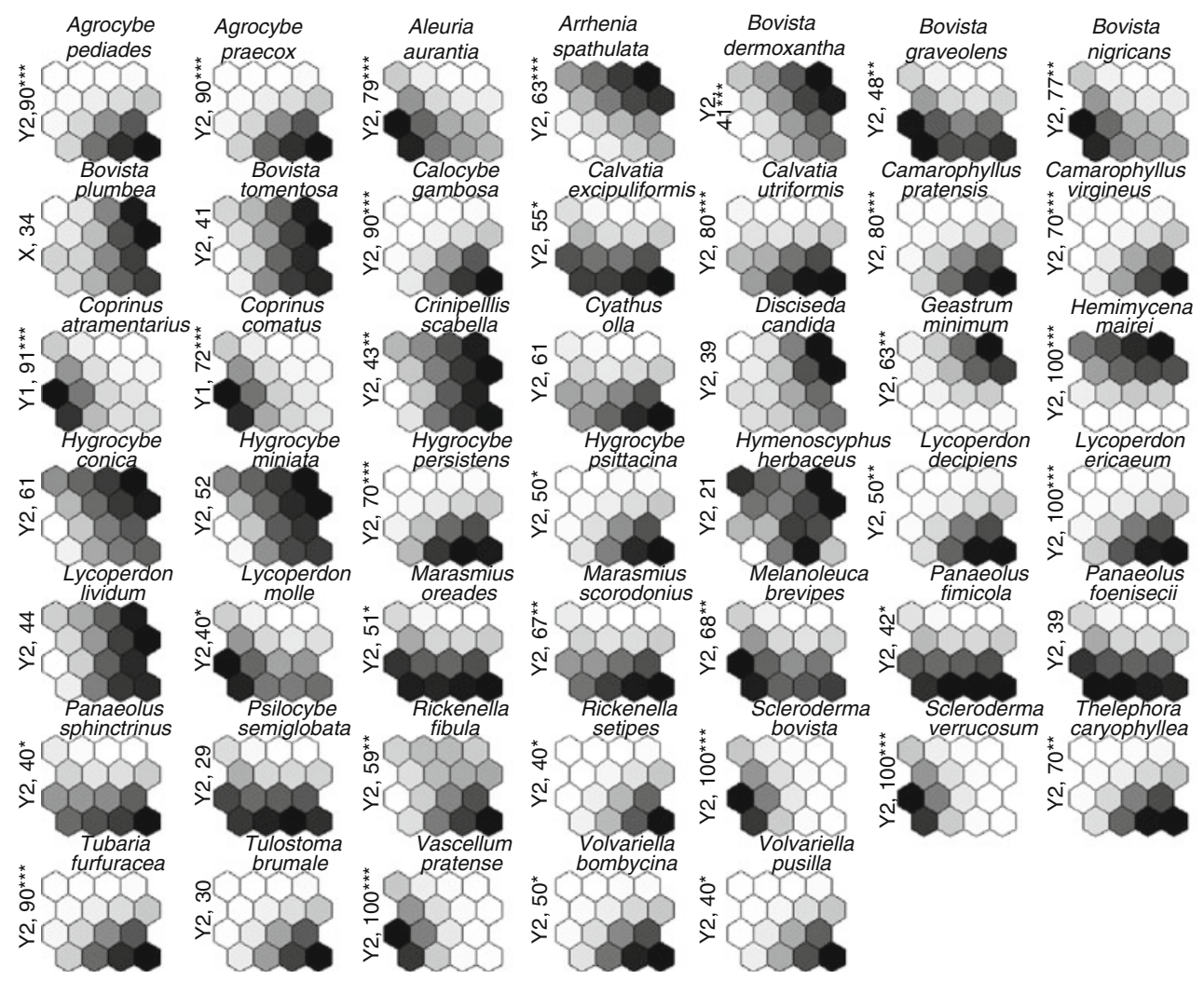

Fig. 2 The importance of the macrofungal species in the SOM according to the most activated regions of the SOM and the IndVal index. The left margin of each figure gives an indicator value (IndVal), and its significance level for a given cluster is marked: ${ }^{*} P<0.05$, $* * P<0.01, * * * P<0.001$

different. The mycobiotes of $\mathrm{OBr}$ and $\mathrm{AB}$ associations were very similar (Fig. 1).

The FP sites were characterized by very poor species composition of macrofungal communities (Table 1). They consist of fungi growing on mosses (Arrhenia spathulata) and grass (Hemimycena mairei), which produce small fruiting bodies, and some xerophilous species, e.g., Disciseda candida, Bovista plumbea and B. tomentosa.
Sites of dense xerothermic swards $(\mathrm{OBr}$ and $\mathrm{AB})$ were richest in species of macromycetes. The majority of macrofungus species occur on these xerothermic swards (e.g., Calocybe gambosa, Camarophyllus pratensis, C. virgineus, Hygrocybe persistans, Mariasmius oreades, Panaeolus foemisecii) were noted by various authors (e.g., Arnolds 1981; Gumińska 1997; Adamczyk et al. 2004) from the plant communities of the alliances 
Table 2 Species distinguished by the IndVal index as significant in self-organizing map (SOM) clusters for xerothermic swards of the Częstochowa Upland. The IndVal value is indicated after the species name

Clusters

\begin{tabular}{|c|c|c|}
\hline$X$ & Y1 & Y2 \\
\hline $\begin{array}{l}\text { Arrhenia spathulata } 63^{* * *} \\
\text { Geastrum minimum } 60^{* *} \\
\text { Hemimycena mairei } 100^{* * *}\end{array}$ & $\begin{array}{l}\text { Aleuria aurantia } 79 * * * \\
\text { Bovista graveolens } 48 * \\
\text { Bovista nigricans } 77 * * \\
\text { Coprinus atramentarius } 91 * * * \\
\text { Coprinus comatus } 72 * * * \\
\text { Lycoperdon molle } 40^{*} \\
\text { Marasmius oreades } 51^{*} \\
\text { Melanoleuca brevipes } 68^{* *} \\
\text { Scleroderma bovista } 100^{* * *} \\
\text { Scleroderma verrucosum } 100^{* * *} \\
\text { Vascellum pratense } 100^{* * *}\end{array}$ & $\begin{array}{l}\text { Agrocybe pediades } 90^{* * *} \\
\text { Agrocybe praecox } 90^{* * *} \\
\text { Calocybe gambosa } 90^{* * *} \\
\text { Calvatia excipuliformis } 55^{*} \\
\text { Calvatia utriformis } 80^{* * *} \\
\text { Camarophyllus pratensis } 80^{* * *} \\
\text { Camarophyllus virgineus } 70^{* * *} \\
\text { Crinipellis scabella } 43^{* *} \\
\text { Hygrocybe persistens } 70^{* * *} \\
\text { Hygrocybe psittacina } 50^{*} \\
\text { Lycoperdon decipiens } 50^{* *} \\
\text { Lycoperdon ericaeum } 100^{* * *} \\
\text { Marasmius scorodonius } 67 * * \\
\text { Panaeolus fimicola } 42 * \\
\text { Panaeolus sphinctrinus } 40 * \\
\text { Rickenella fibula } 59 * * \\
\text { Rickenella setipes } 40^{*} \\
\text { Thelephora caryophyllea } 70^{* *} \\
\text { Tubaria furfuracea } 90^{* * *} \\
\text { Volvariella bombycina } 50^{*} \\
\text { Volvariella pusilla } 40^{*}\end{array}$ \\
\hline
\end{tabular}

$* P<0.05, * * P<0.01, * * * P<0.001$

Arrhenatherion elatoris and Cynosurion. There are also a few xerophilous, saprobic species (e.g., Bovista graveolens, B. tomentosa, Lycoperdon molle) and one mycorrhizal species, Thelephora caryophyllea. Macromycetes of $\mathrm{OBr}$ and $\mathrm{AB}$ associations contain several species observed in steppe habitats, such as Agrocybe pediades, Bovista plumbea, Calvatia utriformis and Coprinus comatus (Kenan and Yuzuf 2002). Macrofungi of the DA association are mainly xerophilous species from the genera Scleroderma, Bovista, Lycoperdon and Vascellum, while macrofungi from the genus Coprinus were observed in many different (natural or anthropogenic) habitats.

The richness of macrofungal communities in each xerothermic sward association and the presence of indicator species (with significant IndVal) of macrofungi are connected with different habitat factors in the investigated phytocoenoses. The Festucetum pallentis association is characterized by a thin humus layer and low humidity (Babczyńska 1978). These conditions are preferred by a very small group of macrofungal species. Most of these species were only found in this association (Adamczyk 2009; Wojewoda 1974, 1975). However, Arrhenia spathulata - a species associated with mosses - was found in a variety of locations. Arrhenia spathulata appears to be a species that grows often on poor habitats; e.g., it was noted on mosses in the sandy dunes of Sicily (Lantieri et al. 2008). Two phytosociologically similar plant associations, Origano-Brachypodietum and Adonido-Brachypodietum pinnati, are located in areas with higher humidity and the richest soils. They are preferred by a large group of macrofungi comprising less specialized species that are found in other plant associations. Diantho-Armerietum elongatae occur on sandy, poor soils (Babczyńska 1978). This habitat is preferred by typically xerophilous macrofungi (Table 2). Interestingly, a majority of indicator species in xerothermic swards are saprotrophic macrofungi. Only Scleroderma bovista, S. verrucosum and Thelephora caryophyllea are mycorrhizal species. Geastrun minimum and macrofungi from the genus Hygrocybe may create symbiotic relations with trees (Wojewoda 2003), but this has not been confirmed. One species, Rickenella fibula, parasitizes mosses (Elborn 2008).

The present research on macrofungal communities confirmed the phytosociological differences between the Festucetum pallentis association and other associations from the class Festuco-Brometea. The results also showed that communities of macrofungi with close associations in terms of phytosociology are very similar, e.g., Origano-Brachypodietum and Adonido-Brachypodietum pinnati.

Thus far, the studies on xerothermic swards (e.g., Stasińska 2005; Wojewoda 1975) have analyzed macrofungi from the mycoenological point of view. These studies did not show the differences between macrofungal communities in different associations of xerothermic swards. In my work, clustering of macrofungi samples in xerothermic swards showed clearly that the structure of macrofungal communities depends on the type of plant association. Macrofungal communities can be good indicators of the habitat diversity of these plant associations; they may also be used to identify modified, degraded and disturbed sites and thus to evaluate phytocoenoses. Using the SOM, both ecological assessments can be conducted easily (Kruk 2006) at various spatial scales. Additionally, the grouping of macrofungi 
samples by SOM has certain advantages: (1) it does not require a priori knowledge about species requirements; and (2) it takes into consideration all species.

Studies by Magura et al. (2001, 2002) and Whitehouse and Bayley (2005) concluded that immobile organisms are characterized by high and stable IndVal values. This pattern was confirmed by the present research. The majority of recognized macrofungal species $(73 \%)$ had high IndVal numbers. This suggests a very important role of macrofungi in semi-natural, unstable phytocoenoses, whose existence depends on intensive human activity (exploitation as pastures, and mowing of grasses). The IndVal is a particularly effective tool for ecological bioindication (MacGeoch et al. 2002; Paavola et al. 2003; Penczak 2009). The results of the present mycological investigations of xerothermic swards demonstrate the value of macrofungi as bioindicators that can be useful in the practical conservation of rare and endangered plant communities.

Acknowledgments I would like to thank T. Penczak and A. Kruk for their comments on the SOM and IndVal results interpretation, and drawing SOM figures. I thank Łukasz Głowacki for his help in improving the English in this paper. Especial thanks are directed to the American Journal Experts for final English correction.

Open Access This article is distributed under the terms of the Creative Commons Attribution Noncommercial License which permits any noncommercial use, distribution, and reproduction in any medium, provided the original author(s) and source are credited.

\section{References}

Adamczyk J (2009) Grzyby wielkoowocnikowe zróżnicowanych zbiorowisk muraw kserotermicznych projektowanego rezerwatu krajobrazowego Olsztyńskie Skały (Wyżyna Częstochowska) (in Polish with English summary). Parki Nar Rez Przyr 28:101-108

Adamczyk J, Głowacki Ł, Penczak T (2004) Structure of macrofungus communities in different habitats of small postglacial ponds margins. Acta Oecol 25:53-60

Arnolds E (1981) Ecology and coenology of macrofungi in grasslands and moist heathlands in Drenthe, the Netherlands. Part.1: Introduction to synecology. Bibl Mycol 83:1-410

Arnolds E (1994) Mycocoenology of stands of Fagus sylvatica L. in the northeastern Netherlands. Phytocoenologia 24:507-530

Babczyńska B (1978) Zbiorowiska murawowe okolic Olsztyna koło Częstochowy. Prace Nauk Uniw Śl 234 (in Polish with English summary). Acta Biologica 5:169-215

Babczyńska-Sendek B (1984) Zbiorowiska łąkowe i murawowe Wyżyny Częstochowskiej, (in Polish with English summary). $\mathrm{PhD}$ thesis, Uniwersytet Sląski Katowice

Bedoya D, Novotny V, Manolakos ES (2009) Instream and offstream environmental conditions and stream biotic integrity importance of scale and site similarities for learning and prediction. Ecol Model 220:2393-2406

Céréghino R, Park YS (2009) Review of the self-organizing map (SOM) approach in water resources: commentary. Environ Model Softw 24:945-947

Chmiel MA (2006) A checklist of Polish larger Ascomycetes. In: Mirek Z (ed) Biodiversity of Poland, vol 8. PAN, Kraków

Cho SB (1997) Self-organizing map with dynamical mode-splitting: application to handwritten digit recognition. Neural Comput 9:1345-1355
Chon KH, Park TS, Moon YS, Cha EY (1996) Patternizing communities by using an artificial neural network. Ecol Model 90:69-78

Dennis RWG (1978) British Ascomycetes. Cramer, Vaduz

Dufrene M, Legendre P (1997) Species assemblages and indicator species: the need for a flexible asymmetrical approach. Ecol Monogr 67:345-356

Dylikowa A (1973) Geografia Polski. Krainy geograficzne (in Polish). Państw. Zakł Wyd Szkol Warszawa

Elborn SA (2008) Rickenella Raithelh. In: Knudsen H, Vesterholt J (eds) Funga Nordica. Agaricoid, boletoid and cyphelloid genera. Nordsvamp, Copenhagen, pp 69-70

Fraiture A (2004) Recherches mycocoenologiques dans les chênaies à charme u Pulmonario-Carpinetum et quelques autres associations forestières de haute Belgique. Thesis, Université Catholique de Louvin, Faculté des Sciences

Fraiture A (2008) Mycocoenologie des forêts de Haute Belgique. Bull Soc Mycol Fr 124(3-4):187-261

Giraudel JL, Lek S (2001) A comparison of self-organizing map algorithm and some conventional statistical methods for ecological community ordination. Ecol Model 146:329-339

Gumińska B (1997) Flora Polska, Grzyby (Mycota) Basidiomycetes, Hygrophoraceae, vol 26 (in Polish). Kraków

Hereźniak J (2002) Rezerwaty przyrody ziemi częstochowskiej. Studium przyrodniczo-historyczne (in Polish). LOP Zarząd Okręgu w Częstochowie

Hereźniak J (2004) Z Jurajskim Parkiem Narodowym do Unii Europejskiej (in Polish). Częstochowskie Towarzystwo Naukowe Częstochowa

Kalteh AM, Hjorth P, Berndtsson R (2008) Review of the selforganizing map (SOM) approach in water resources: analysis, modelling and application. Environ Model Softw 23:835-845

Kenan D, Yuzuf U (2002) Macrofungi of Ağri Province. Turk J Bot 26:291-295

Kohonen T (1982) Self-organized formation of topologically correct feature maps. Biol Cyber 63:201-208

Kondracki J (1998) Geografia regionalna Polski (in Polish). Wydawnictwo Naukowe PWN, Warszawa

Kruk A (2006) Self-organizing maps in revealing in non-obligatory riverine fish in long-term data. Hydrobiologia 553:43-57

Kruk A, Lek S, Park YS, Penczak T (2007) Fish assemblages in the large lowland Narew River system (Poland): application of the self-organizing map algorithm. Ecol Model 203:45-61

Krzakowa M, Michalak M (2007) Genetic variability of selected marginal populations of Stipa capillata L. Biol Lett 44(2): $127-135$

Lantieri A, Gargano ML, Venturella G (2008) The sabulicolous fungi from Sicily (southern Italy): addition and critical review. Mycotaxon 110:151-154

Lasne E, Lek S, Laffaille P (2007) Patterns in fish assemblages in the Loire floodplain: the role of hydrological connectivity and implications for conservation. Biol Conserv 139:258-268

Ławrynowicz M (1973) Grzyby wyższe makroskopowe w grądach Polski środkowej [Higher macroscopic fungi in the oakhornbeam forests of the Central Poland]. Acta Mycol 9(2):133-204

MacCune B, Mefford MS (1992) PcOrd multivariate analysis of ecological data, version 2.0. MjM Software Design, Gleneden Beach, OR

MacGeoch MA, Van Rensburg BJ, Botes A (2002) The verification and application of bioindicators: a case study of dung beetles in savanna ecosystem. J Appl Ecol 39:661-672

Magura T, Tóthmérész B, Molnár T (2001) Forest edge and diversity: carabids along forest-grassland. Biodivers Conserv 10:287-295

Magura T, Elek Z, Tóthmérész B (2002) Impacts of non-native spruce reforestation on ground beetles. Eur J Soil Biol 38:291-295

Matuszkiewicz M (2001) Przewodnik do oznaczania zbiorowisk roślinnych Polski (in Polish). Vademecum Geobotanicum, Wydawnictwo Naukowe PWN, Warszawa 
Noori R, Karbassi A, Sabahi MS (2010) Evaluation of PCA and Gamma test techniques on ANN operation for weekly solid waste prediction. J Environ Manage 91:767-771

Olaczek R (1998) Przyroda Polski pod ochroną (in Polish). Zarząd Główny LOP, Warszawa

Paavola R, Muotka T, Virtanen R, Heino J, Krevi P (2003) Are biological classification of headwater streams concordant across multiple taxonomic groups? Freshw Biol 48:1912-1923

Park YS, Céréghino R, Compin A, Lek S (2003) Applications of artificial neural networks for patterning and predicting aquatic insect species richness in running waters. Ecol Model 160:265-280

Park YS, Lek S, Scardi M, PFM Verdonschot, Jřrgensend SE (2006) Patterning exergy of benthic macroinvertebrate communities using self-organizing maps. Ecol Model 195:105-113

Penczak T (2009) Fish assemblage compositions after implementation of the IndVal method on the Narew River System. Ecol Model 220:419-423

Penczak T, Kruk A, Park YS, Lek S (2005) Patterning spatial variation in fish assemblage structures and diversity in the Pilica River system. In: Lek S, Scardi M, Verdonschot PFM, Descy JP, Park YS (eds) Modelling community structure in freshwater ecosystems. Springer, Berlin, pp 100-113

Penczak T, Agostinho AA, Gomes LC, Latini JD (2009) Impacts of a reservoir on fish assemblages of small tributaries of the Corumbá River, Brazil. Riv Res Appl 25:1013-1024

Stasińska M (2005) Macromycetes of xerothermic swards of the Western Pomerania (NW) Poland. Acta Mycol 40(1):133-140
Stasińska M (2008) The state of knowledge of Macromycetes in xerothermic grasslands in Poland. Ann Univ Marie CurieSkłodowska Lublin-Polonia sectio C 63(1/5):71-78

Szafer W (1977) Szata roślinna Polski niżowej. In: Szafer W, Zarzycki K (eds) Szata roślinna Polski. Wyd 3 Wydawnictwo Naukowe PWN, Warszawa

Versanto J, Himberg J, Alhoniemi E, Parhankangas J (2000) SOM Toolbox for Matlab 5. Technical report A57. Neural Networks Research Centre, Helsinki University of Technology, Helsinki

Whitehouse HE, Bayley E (2005) Vegetation patterns and biodiversity of peatland plant communities surrounding mid-boreal wetland ponds in Alberta, Canada. Can J Bot 83:621-637

Wojewoda W (1974) Macromycetes Ojcowskiego Parku Narodowego (in Polish with English summary). I. Flora. Acta Mycol $10: 181-265$

Wojewoda W (1975) Macromycetes Ojcowskiego Parku Narodowego. II. Charakterystyka socjologiczno-ekologiczno-geograficzna (in Polish with English summary). Acta Mycol 11:163-209

Wojewoda W (1977) Grzyby wielkoowocnikowe. In: Zabierowski K (ed) Przyroda Ojcowskiego Parku Narodowego (in Polish). Studia Naturae B 28:161-181

Wojewoda W (2003) Checlist of polish larger Basidiomycetes. Krytyczna lista wielkoowocnikowych grzybów podstawkowych Polski (in Polish with English summary). Inst Bot im W Szafera PAN Kraków 